Article

\title{
Carbon Footprint Estimation Tool for Residential Buildings for Non-Specialized Users: OERCO2 Project
}

\author{
Jaime Solís-Guzmán ${ }^{1}$, Cristina Rivero-Camacho ${ }^{1}$, Desirée Alba-Rodríguez ${ }^{1}$ (D) \\ and Alejandro Martínez-Rocamora ${ }^{2, *(D)}$ \\ 1 ArDiTec Research Group, Department of Architectural Constructions II, \\ Higher Technical School of Building Engineering, University of Seville, Av. Reina Mercedes, \\ 4-a. 41012 Seville, Spain; jaimesolis@us.es (J.S.-G.); crivero1@us.es (C.R.-C.); malba2@us.es (D.A.-R.) \\ 2 GACS Research Group, Department of Construction Sciences, Faculty of Architecture, \\ Construction and Design, University of Bío-Bío, Av. Collao, 1202 Concepción, Chile \\ * Correspondence: amartinez@ubiobio.cl; Tel.: +56-413-111-716
}

Received: 29 March 2018; Accepted: 24 April 2018; Published: 27 April 2018

\begin{abstract}
Existing tools for environmental certification of buildings are failing in their ability to reach the general public and to create social awareness, since they require not only specialized knowledge regarding construction and energy sources, but also environmental knowledge. In this paper, an open-source online tool for the estimation of the carbon footprint of residential buildings by non-specialized users is presented as a product from the OERCO2 Erasmus + project. The internal calculations, data management and operation of this tool are extensively explained. The ten most common building typologies built in the last decade in Spain are analysed by using the OERCO2 tool, and the order of magnitude of the results is analysed by comparing them to the ranges determined by other authors. The OERCO2 tool proves itself to be reliable, with its results falling within the defined logical value ranges. Moreover, the major simplification of the interface allows non-specialized users to evaluate the sustainability of buildings. Further research is oriented towards its inclusion in other environmental certification tools and in Building Information Modeling (BIM) environments.
\end{abstract}

Keywords: life-cycle assessment; carbon footprint; construction materials; non-specialized users; estimation tool; environmental impact assessment; social awareness; sustainability; residential buildings

\section{Introduction}

In recent decades, regulations at national and international level have reflected both a growing concern about the environmental impact caused by the construction sector, and the consequent focus on the reduction of the carbon footprint generated by the manufacture of construction materials, which has been identified as the cause of more than $40 \%$ of the total impact of the construction phase in the life cycle of a building [1,2]. This goal is not always easy to achieve, since there are economic, technical, practical, and cultural barriers that prevent professionals from selecting materials with low carbon emissions. These include time constraints during the design phase, the high cost of new products and additional professional training, the difficulties for small industries competing against established industries, a lack of full-scale demonstration projects, and negative perceptions amongst practitioners and clients [2,3]. In order to promote the use of sustainable materials, various procedures have been proposed: for labelling control and environmental product declarations (EPD) [4-7], for the application of life-cycle assessment (LCA) methodologies in the building sector [8-10], and for the sustainable management of buildings [11,12]. 
One of the most extended LCA methodologies available currently is the carbon footprint (CF), which consists of determining the emissions of greenhouse gases produced by a certain process [13]. The fact that it is strongly related to the main aims of the Kyoto Protocol, along with the ease with which it can be understood by the general non-specialized public [14] and its simple application in decision-making and environmental policy [15] are key to the success of this indicator. However, the application of LCA methodologies in the construction sector is complicated and results vary across studies. This is due to the fact that the existing standards have failed to establish an exact methodology, and researchers therefore use their own interpretations of these standards [16].

Most recent studies that attempt to estimate the environmental impact of buildings [17] have been subject to reviews that focus on LCA [18], life-cycle energy analysis [19], or life-cycle carbon footprint [20], or a combination of these [21,22]. Comparing the results from these studies is problematic due to the variety of assumptions and decisions that must be made in the assessment process (service life of the building and materials, maintenance operations, energy consumption of the building, building typology, calculation formulae, etc.). However, the following conclusions are generally drawn:

- The manufacturing and construction phase of a building's life cycle, which is usually concentrated into a short period of time (1-2 years), causes the most intensive environmental impact. This is mainly due to the consumption of concrete and steel for the structure, both of which represent a high percentage of the emissions produced during this phase [23,24]. This impact is reduced the longer the building's service life is considered; however, the decisions made during this phase greatly influence the results of the other life-cycle phases of the building.

- The use and maintenance phase is generally responsible for $80-90 \%$ of the $\mathrm{CO}_{2}$ emissions generated during a building's life cycle [25], almost $60 \%$ of which is caused by the energy demand for heating and air-conditioning [26]. An operational phase of more than 50 years duration reduces emissions and this should be a primary goal.

- $\quad$ Reductions in energy consumption during the use and maintenance phase should be achieved through decisions made during the design phase, which implies the use of materials with a higher embodied energy. This means that, in nearly-zero-energy buildings, the emissions during the construction phase represent a higher percentage of the total emissions of the entire life cycle [27]. Therefore, once the operational energy has been reduced, attention should be focused on the development of new insulation materials that require less energy to manufacture [28].

The knowledge generated by the significant number of studies on environmental impact is reflected in the development of calculation tools, which are usually oriented towards the environmental certification of buildings. The development of tools that enable us to measure the sustainability of buildings has intensified in recent years in order to promote policies that demand minimum sustainable standards in buildings.

Currently, there are a number of tools available in Spain that enable the carbon footprint of buildings to be calculated. Despite the more widespread use of translated versions from internationally known methodologies such as LEED and BREEAM, which also allow recognized sustainability certification to be obtained for buildings, in recent years national alternatives have been developed from research projects.

LEED and BREEAM are managed nationally by the Spain Green Building Council [29] and BREEAM Spain [30], respectively, and they evaluate various criteria to obtain a final score. The criteria include for example, the $\mathrm{CO}_{2}$ emissions generated by the manufacturing of the construction materials used and the energy consumed in the operational phase of the building. While both of these methodologies require the quantification of the $\mathrm{CO}_{2}$ emissions by a certified professional in order to assign a score to the corresponding section, these quantifications are not numerically reflected in the final certificate, which is based only on the total score. At the national level, Green Building Council (GBC) Spain offers VERDE certification tools [31], which focus on design assistance (HADES), new buildings (VERDE NE), rehabilitation (VERDE RH), and urban development (VERDE DU). 
These assign the highest score percentage ( $25 \%)$ to greenhouse gas emissions, as a demonstration of the importance of preventing the environmental impacts of emissions. Additionally, ECOMETRO is a web-based open-source tool for the measurement of the environmental impact of a building [32], and is similar to an EPD, but is applied to entire buildings.

On the other hand, energy certification tools, such as CE3, CE3X, CERMA [33], and the Unified Tool LIDER-CALENER [34], developed by Spanish associations and universities, and CYPETHERM [35], developed by CYPE Ingenieros, estimate $\mathrm{CO}_{2}$ emissions caused by the energy demand during the operational phase of a building, without taking into account the emissions from the construction materials consumed.

Several other specialized platforms also exist that allow for the detailed calculation of $\mathrm{CO}_{2}$ emissions based on a project's bill of quantities, such as: the BEDEC cost database [36], developed by the Institute of Construction Technology of Catalonia, whose environmental data comes from the Ecoinvent LCA database [37], well-known for being one of the most comprehensive databases at European level [38] and for its integration with the Simapro LCA software [39]; and the SOFIAS tool, currently in its test version [40], with data from the OpenDAP database. As an intermediate solution, E2CO2Cero, funded by the Basque Government, is a software package that enables the embodied energy and carbon footprint of a building to be calculated, according to the materials consumed and the construction processes used for that phase of the life cycle [41]. There are two available versions of this software, the complete version, which requires the introduction of the project's bill of quantities by the user, and the simplified version, which estimates the environmental impact from basic information that the user provides about the building.

These tools, however, fail to achieve what should be a key objective in the general strategy, that is, the ability to reach the general public to create social awareness. Most of these tools require not only specialized knowledge regarding construction and energy sources, but also environmental knowledge. As a consequence, non-specialized users are incapable of auto-evaluation in order to obtain even a general idea of how sustainable their own house or building is, and how they might improve its environmental behaviour. In this case, non-specialized users are defined as those that, even if they possess technical knowledge (architecture or construction students, professionals from the construction sector, etc.), have not been trained in the assessment of the environmental impacts generated by construction processes.

In this paper, a carbon footprint estimation tool for residential buildings is presented that has been designed for non-specialized users, which constitutes part of the main objectives of the OERCO2 project, oriented towards the transference of knowledge to society regarding the assessment of $\mathrm{CO}_{2}$ emissions through an open online platform.

\section{Materials and Methods}

\subsection{OERCO2 Project}

The OERCO2 project (http: / / oerco2.eu/) is funded by the Erasmus + program in 2016 within the scope of Strategic Associations in the Higher Education sector (KA203). The University of Seville (Spain) leads the project, and the partners are: Technological Centre of the Marble (Murcia, Spain), CERTIMAC (Faenza, Italy), Green Building Council (Bucharest, Romania), CTCV (Coimbra, Portugal), and the University of Transylvania (Brasov, Romania).

The main aims of the project include:

- Studying the methodology for the calculation of $\mathrm{CO}_{2}$ emissions of the construction process and throughout the life cycle of materials at European level.

- Establishing a common European curriculum in this area, thus increasing awareness of climate change and providing information on the emissions generated by each element.

- Developing an Open Educational Resource (OER) to spread knowledge on $\mathrm{CO}_{2}$ emissions in construction processes. 
- Launching an online tool accessible to all building agents (students, professionals, etc.) at European level. Specialized knowledge on the environmental impact of building processes is not necessary for its use.

In order to achieve these goals, four milestones have been established in the project: developing a state-of-the-art review of the existing environmental regulations concerning every production sector involved in the construction process, and of the implementation level of those regulations in the countries participating in the OERCO2 project; studying the existing environmental product declarations (EPD) of construction products in these countries; studying the various calculation methodologies of $\mathrm{CO}_{2}$ emissions for construction processes in the participant countries; and finally, developing the OERCO2 platform, where an application will be hosted that enables $\mathrm{CO}_{2}$ emissions of construction processes to be estimated.

\subsection{OERCO2 Tool}

The OERCO2 tool (accessible at http:/ / co2tool.oerco2.eu/) is an online application that enables the carbon footprint produced in the construction of residential buildings to be estimated. It stems from several previous research studies developed by the authors [1,42-45] and includes the evaluation of $\mathrm{CO}_{2}$ emissions for the construction process of 140 different residential building typologies. For the embodied energy assessment, the tool uses a cradle-to-site LCA analysis, that is, A1 to A5 life-cycle phases, which correspond to manufacturing (A1-A3) and construction (A4-A5). The environmental data included in the OERCO2 tool was obtained from the Ecoinvent database through Simapro. In order to obtain the $\mathrm{CO}_{2}$ emissions embodied into construction materials, their Life-Cycle Inventory (LCI) is analysed by applying the IPCC 100a methodology, which is used by the Carbon Footprint indication since it isolates $\mathrm{CO}_{2}$ and other GHG emissions from the LCI. The tool has been tested and evaluated by all partners from the project, and it is considered that it includes all the building typologies and characteristics commonly used in Spain, Portugal, Italy and Romania, which are essentially those of any European country.

The methodology for the evaluation of the carbon footprint of the construction of residential buildings is based on the projects' bill of quantities and a classification system for construction work which breaks down this information on materials, manpower and machinery needs. The budgets of 140 different projects are analysed and classified; their budgets are reorganized in a construction-work breakdown system (CBS) that facilitates comparison. This organization system has been successfully applied in previous research to estimate the generation of construction waste [46] and to evaluate the ecological footprint of buildings $[1,43,45,47,48]$.

In particular, the present model employs the Andalusia Construction Information Classification System (ACICS) [49]. Its most extended use is for the estimation of costs in the construction sector and it is mandatory in public works in Andalusia (Spain). ACICS uses a hierarchical organization for work units, where the highest level is the construction site, followed by categories called chapters, each representing a construction process (e.g., earthworks, foundations, installations, etc.), which are subsequently divided into sub-chapters. The base of this structure is formed by basic costs (BC), corresponding to elementary resources (materials, machinery and manpower), which aggregate to form auxiliary costs (AC), usually mixes materials such as cement mortar, gypsum plaster, or manpower teams, and simple costs (SC), representing the various activities or work units (Table 1). These three kinds of costs are employed by the OERCO2 tool for its calculations.

The data obtained from each project's bill of quantities is structured according to the aforementioned ACICS [49], and is expressed in units per built surface $\left(\mathrm{u} / \mathrm{m}^{2}\right)$. From the 140 projects evaluated, the mean quantities of each activity $\left(\mathrm{Q}_{\mathrm{i}}\right)$ are obtained through a statistical process for each building typology. These mean quantities are then transformed into materials, manpower and machinery needs by combining ACICS with a resource quantification database. The quantities of the various resources involved can then be evaluated by applying the carbon footprint methodology in order to obtain the $\mathrm{CO}_{2}$ emissions generated due to the whole construction process. 
The OERCO2 tool is structured with an initial screen where the user specifies general information regarding the project to be analysed, such as the number of floors, type of structure, and built-up surface area (Table 2). The selection of this initial data enables a similar project to be assigned from which the associated $Q_{i}$ are gathered [1].

Table 1. Internal cost classification structure [50].

\begin{tabular}{ll}
\hline \multicolumn{1}{c}{ Class Levels } & \multicolumn{1}{c}{ Definitions } \\
\hline L1. Construction site & All the constructive elements that give up a construction site \\
\hline L2. Chapter & $\begin{array}{l}\text { Element sets with a common characteristic. } \\
\text { e.g., } 05 . \text { Structures. }\end{array}$ \\
\hline L3. Sub-chapter & $\begin{array}{l}\text { Chapter division into smaller sets with a common characteristic. } \\
\text { e.g., 05H. Reinforced concrete. }\end{array}$ \\
\hline L4. Sections & $\begin{array}{l}\text { Sub-Chapter division into smaller sets with a common } \\
\text { characteristic. } \\
\text { e.g., 05HH. Concrete. }\end{array}$ \\
\hline L5. Groups & $\begin{array}{l}\text { Section division into smaller sets with a common characteristic. } \\
\text { e.g., 05HHJ. Reinforced concrete beam. }\end{array}$ \\
\hline L6. Work units & $\begin{array}{l}\text { Group division into unitary elements. } \\
\text { e.g., 05HHJ0001 m3 Concrete HA-25 in... }\end{array}$ \\
\hline
\end{tabular}

Table 2. Options for project configuration in the OERCO2 software tool.

\begin{tabular}{|c|c|c|c|}
\hline & Unit & Concept & Tool Options Available \\
\hline \multirow{4}{*}{ INIT. INF. } & & Num. Floors & \\
\hline & $\mathrm{N} / \mathrm{A}$ & Num. floors & $1 / 2 / 3 / 4 / 5 / 6+$ \\
\hline & $\mathrm{N} / \mathrm{A}$ & Num. undergr. floors & $0 / 1 / 2 / 3 / 4$ \\
\hline & $\mathrm{N} / \mathrm{A}$ & Shops in ground floor & No/Yes \\
\hline \multirow{4}{*}{ C.02 } & & Earthworks & \\
\hline & $\mathrm{m}^{3}$ & Excavations & Excavator/Backhoe/Not applicable \\
\hline & $\mathrm{m}^{3}$ & Fillings & Manual means/Mechanic means/Not applicable \\
\hline & $\mathrm{m}^{3}$ & Earth transport & Manual means/Mechanic means/Not applicable \\
\hline \multirow{2}{*}{ C.03 } & & Foundations & \\
\hline & $\mathrm{m}^{3}$ & Footings & Isolated/Slab/Strip/Piles (m) \\
\hline \multirow{4}{*}{ C. 04} & & Sewer System & \\
\hline & $\mathrm{u}$ & Manholes & In situ/Prefabricated \\
\hline & $\mathrm{m}$ & Sewage pipes & PVC/Concrete/Fibre-cement/Polyethylene \\
\hline & $\mathrm{m}$ & Downpipes and roof sinks & $\begin{array}{l}\text { Zinc sheet/Steel sheet/Reinforced } \\
\text { PVC/Polypropylene/Fibre-cement }\end{array}$ \\
\hline \multirow{4}{*}{ C. 05} & & Structure & \\
\hline & $\mathrm{m}^{2} / \mathrm{m}^{3}$ & Supports & Brick wall/Reinforced concrete \\
\hline & $\mathrm{m}^{2}$ & Floor slabs & $\begin{array}{l}\text { Waffle slab w/non-recoverable caissons/Waffle slab } \\
\mathrm{w} / \text { recoverable caissons/One-way slab w/ceramic } \\
\text { vaults/One-way slab w/concrete vaults/Solid slab }\end{array}$ \\
\hline & $\mathrm{m}^{2}$ & Formwork & Wood/Metal \\
\hline
\end{tabular}


Table 2. Cont.

\begin{tabular}{|c|c|c|c|}
\hline \multirow{4}{*}{ C. 06} & \multicolumn{3}{|c|}{ Masonry } \\
\hline & $\mathrm{m}^{2}$ & Façades & $\begin{array}{l}1 \mathrm{ft} \text { brick wall } \mathrm{w} / \text { chamber } / 1 / 2 \mathrm{ft} \text { brick wall } \\
\mathrm{w} / \text { chamber } / 1 \mathrm{ft} \mathrm{w} / \mathrm{o} \text { chamber } / 1 / 2 \mathrm{ft} \mathrm{w} / \mathrm{o} \\
\text { chamber } / 1 \mathrm{ft} \mathrm{w} / \text { chamber }+ \text { plasterboard } / 1 / 2 \mathrm{ft} \\
\mathrm{w} / \text { chamber + plasterboard / Lightweight concrete } \\
\text { block wall }\end{array}$ \\
\hline & $\mathrm{m}^{2}$ & Claddings & $\begin{array}{l}\text { Ceramic brick/Single layer mortar/Cement } \\
\text { mortar/Plastic paint/Cement paint/Ventilated } \\
\text { cladding (natural stone/ceramic/resin/cellulose- } \\
\text { cement/wooden sandwich panel + XPS/Cladding } \\
\text { (artificial stone/limestone/marble/granite/wood) }\end{array}$ \\
\hline & $\mathrm{m}^{2}$ & Partitions & $\begin{array}{l}\text { Double hollow brick } 9 \mathrm{~cm} / 24 \mathrm{~cm} / \text { Triple hollow } \\
\text { brick } 15 \mathrm{~cm} / \text { Plasterboard }\end{array}$ \\
\hline \multirow{3}{*}{ C. 07} & \multicolumn{3}{|c|}{ Roof } \\
\hline & $\mathrm{m}^{2}$ & Flat & $\begin{array}{l}\text { Non-passable and ventilated/Non-passable and } \\
\text { non-ventilated/Non-passable and inverted/Passable } \\
\text { and ventilated/Passable and non-ventilated/ } \\
\text { Passable and inverted/Does not apply }\end{array}$ \\
\hline & $\mathrm{m}^{2}$ & Sloping & $\begin{array}{l}\text { Wavy fibre-cement sheet/Sandwich insulating } \\
\text { panel/Aluminium sheet/Galvanized steel } \\
\text { sheet/Polyester/Slate tiles/Ceramic tiles/Cement } \\
\text { tiles/Does not apply }\end{array}$ \\
\hline \multirow{15}{*}{ C. 08} & \multicolumn{3}{|c|}{ Installations } \\
\hline & $\mathrm{u}$ & Air-Cond. System & $\begin{array}{l}\text { Compact/Parted system w/ducts/Heat pump/VRF } \\
\text { Inverter/None }\end{array}$ \\
\hline & $\mathrm{u}$ & Terminal units & Ceiling unit/Console/Apartment type/None \\
\hline & $\mathrm{m}$ & Ducts & Glass fibre/Galvanized steel/None \\
\hline & $\mathrm{m}$ & Pipes & $\begin{array}{l}\text { Built-in galvanized steel/Superficial galvanized } \\
\text { steel/None }\end{array}$ \\
\hline & $\mathrm{m}^{2}$ & Radiators & $\begin{array}{l}\text { Classic steel/Injected aluminium/Iron/Steel } \\
\text { sheet/None }\end{array}$ \\
\hline & $\mathrm{u}$ & Boilers & $\begin{array}{l}\text { Diesel/Solid fuel/Gas wall-mounted/Mix electric } \\
\text { wall-mounted/None }\end{array}$ \\
\hline & $\mathrm{m}$ & Cold-water pipes & $\begin{array}{l}\text { Copper/Galvanized } \\
\text { steel/Polyethylene/Polypropylene }\end{array}$ \\
\hline & $\mathrm{m}$ & Hot-water pipes & Copper/Galvanized steel/Polypropylene \\
\hline & $\mathrm{u}$ & Sinks & PVC/Polypropylene \\
\hline & $\mathrm{m}$ & Ventilation & Concrete/Ceramic/Helical galvanized Steel \\
\hline & $\mathrm{u}$ & Heater & Gas/Electric/Does not apply \\
\hline & $\mathrm{u}$ & Solar panels & Applies/Does not apply \\
\hline & $\mathrm{m}$ & Pipe insulation & Applies/Does not apply \\
\hline & $\mathrm{u}$ & Lift & Applies/Does not apply \\
\hline \multirow[b]{2}{*}{ C. 09} & \multicolumn{2}{|r|}{ Insulation } & \\
\hline & $\mathrm{m}^{2}$ & Thermal-acoustic & $\begin{array}{l}\text { Polystyrene/Polyurethane/Glass fibre/Rock } \\
\text { wool/Perlite/Cork/Polyethylene/None }\end{array}$ \\
\hline
\end{tabular}


Table 2. Cont.

\begin{tabular}{|c|c|c|c|}
\hline \multirow{4}{*}{ C. 10} & \multicolumn{2}{|r|}{ Finishes } & \multirow[b]{2}{*}{ Gypsum plaster/Cement mortar/Does not apply } \\
\hline & $\mathrm{m}^{2}$ & Continuous claddings & \\
\hline & $\mathrm{m}^{2}$ & Floorings & $\begin{array}{l}\text { Ceramic/Stoneware/Continuous } \\
\text { concrete/Hydraulic } \\
\text { tile/Linoleum/Carpet/Cork/Soft-wood } \\
\text { parquet/Floating solid soft-wood/Floating } \\
\text { laminated soft-wood/Hard-wood parquet/Floating } \\
\text { solid hard-wood/Floating laminated } \\
\text { hard-wood/Limestone/Marble/Slate/Granite/ } \\
\text { Terrazzo/Concrete slab }\end{array}$ \\
\hline & $\mathrm{m}^{2}$ & Ceilings & $\begin{array}{l}\text { Continuous plaster w/rods/Continuous plaster } \\
\mathrm{w} / \text { metal fixings/Removable plaster } \\
\text { panels/Continuous laminated gypsum/Removable } \\
\text { laminated gypsum w/hidden support grid }\end{array}$ \\
\hline \multirow{6}{*}{ C. 11} & \multicolumn{3}{|c|}{ Carpentry and Protection Elements } \\
\hline & $\mathrm{m}^{2}$ & Windows & $\begin{array}{l}\text { Pine-wood casement/Lacquered aluminium } \\
\text { sliding/Lacquered aluminium casement } \mathrm{w} \text { /thermal } \\
\text { bridge break/PVC sliding }\end{array}$ \\
\hline & $\mathrm{m}^{2}$ & Doors & Wood/Melamine \\
\hline & $\mathrm{m}^{2}$ & Blinds & Anodized aluminium/PVC/Wood/None \\
\hline & $\mathrm{m}^{2}$ & Protection grids & Hot-rolled steel/None \\
\hline & $\mathrm{m}$ & Railings & Steel/Aluminium/Wood/None \\
\hline \multirow[b]{2}{*}{ C. 12} & \multicolumn{2}{|r|}{ Glass and Synthetics } & \\
\hline & $\mathrm{m}^{2}$ & Glazing & $\begin{array}{l}\text { Thermal-acoustic } 6+12+6 / 6+12+6 \\
\text { low-emissive } / 8+14+5+5 \text { low-emissive argon and } \\
\text { solar control }\end{array}$ \\
\hline \multirow{3}{*}{ C. 13} & \multicolumn{2}{|r|}{ Paintings } & \\
\hline & $\mathrm{m}^{2}$ & Exterior & Plastic paint/Cement paint/Does not apply \\
\hline & $\mathrm{m}^{2}$ & Interior & Plastic paint/Does not apply \\
\hline
\end{tabular}

In the subsequent step, the user specifies data about the project regarding constructive solutions for each element (Table 2). This is then employed by the OERCO2 tool to select which of the available simple costs (SC) must be used for the calculations. As mentioned before, SC are made of BC and AC. In this tool, resources (BC) contain not only economic, but also environmental information (e.g., $\mathrm{CO}_{2}$ emission factors). The environmental data included in the OERCO2 was obtained from the Ecoinvent database through Simapro, and chosen for covering all the commonly employed materials in building construction [38]. In order to obtain the $\mathrm{CO}_{2}$ emissions embodied in construction materials, their Life-Cycle Inventory (LCI) is analysed by applying the IPCC 100a methodology, which is used by the Carbon Footprint indicator since it isolates $\mathrm{CO}_{2}$ and other GHG emissions from the LCI.

Following this logic, when a specific work unit is selected, then an SC is assigned with two different associated factors: an economic cost ( $€ /$ ref. unit) and an environmental cost $\left(\mathrm{kgCO}_{2} \mathrm{eq} / \mathrm{ref}\right.$. unit), where the reference unit is that of the SC selected (Figure 1). The selection of the initial data for the project enables the $Q_{i}$ of that work unit to be gathered, thereby making it possible to obtain the total cost and carbon footprint (CF) for that activity through Equations (1) and (2):

$$
C_{i}=Q_{i} \cdot P_{i} \cdot B_{s}
$$

where $C_{i}$ is the total cost of activity $i(€), Q_{i}$ represents the statistically estimated quantity for activity $i$ in the selected project (ref. unit $\left./ \mathrm{m}^{2}\right), P_{i}$ is the unitary price of activity $i\left(€ /\right.$ ref. unit), and $B_{s}$ is the total built-up surface of the selected project $\left(\mathrm{m}^{2}\right)$; and 


$$
C F_{i}=Q_{i} \cdot U C F_{i} \cdot B_{s}
$$

where $C F_{i}$ is the total carbon footprint of activity $i\left(\mathrm{kgCO}_{2} \mathrm{eq}\right)$ and $U C F_{i}$ is the unitary carbon footprint of activity $i\left(\mathrm{kgCO}_{2} \mathrm{eq} /\right.$ ref. unit).

m UNDERGROUND HDPA PIPE $200 \mathrm{~mm}$.
Underground pipe made of high-density polyethylene (HDPA), with 200 mm nominal diameter
mechanic joints, over $10 \mathrm{~cm}$ thick sand bed, including proportional part of signaling, special parts,
ramming and filling, built according to CTE.

Figure 1. Cost structure and quantification of economic and environmental impacts.

The tool shows the final results for the total construction cost (expressed both in $€$ and $€ / \mathrm{m}^{2}$ ), and total $\mathrm{CF}$ (in $\mathrm{kgCO}_{2} \mathrm{eq}$ and $\mathrm{kgCO} 2 \mathrm{eq} / \mathrm{m}^{2}$ ), the latter also being broken down into materials and machinery (Figure 1).

This in-depth analysis of the way the OERCO2 tool works internally demonstrates that users require no specialized knowledge of the environmental evaluation of construction projects, such as the calculation of the embodied energy or $\mathrm{CO}_{2}$ emission factors associated with construction processes. Instead, users only need to know about the solutions implemented in the construction of the building. The OERCO2 tool has been verified by all the partners in the project in order to include variations among the different countries in construction processes and solutions.

The main current limitation of the calculation methodology used by the OERCO2 tool is the use of a common LCA database for the assessment of each case, since this does not take into account the variability in the energy mix among the different countries involved, thus leading to the corresponding homogeneity regarding $\mathrm{CO}_{2}$ emissions from construction materials. Another limitation is the restrictive variety of solutions for structures, finishes and installations. This issue will be handled in forthcoming updates of the OERCO2 tool, which will include timber structures and recycled materials, as suggested by the initial testers of the tool. The introduction of timber materials is considered crucial given its 
capacity to lower the environmental impact of buildings compared to other materials such as steel or concrete.

\section{Case Studies}

In order to determine the reliability of the OERCO2 tool, a selection of the ten most representative building typologies (from the 140 typologies available) for the construction of residential buildings in Spain over the last ten years was analysed [51] using the CF calculation methodology explained in the previous section.

Table 3 shows a summary of the most relevant features of the studied projects: dwelling type, built-up surface, above-ground and underground floors, and the constructive solutions adopted for the foundations, structure and roof. These parameters will be taken into account in the assessment of the results, since the remaining characteristics of the projects are identical for every case study selected. The sensitivity of the tool to the aforementioned parameters can therefore also be analysed.

Table 3. Characterization of the case studies.

\begin{tabular}{|c|c|c|c|c|c|c|c|}
\hline $\begin{array}{l}\text { Project } \\
\text { Identifier }\end{array}$ & $\begin{array}{c}\text { Dwelling } \\
\text { Type }\end{array}$ & $\begin{array}{c}\text { Built-Up } \\
\text { Surface } \\
\left(\mathrm{m}^{2}\right)\end{array}$ & $\begin{array}{l}\text { Floors } \\
\text { Above } \\
\text { Ground }\end{array}$ & $\begin{array}{l}\text { Underground } \\
\text { Floors }\end{array}$ & Footings & Structure & Roof \\
\hline A & $\begin{array}{l}\text { Detached } \\
\text { house }\end{array}$ & 2696.57 & 1 & 0 & Strip & Brick walls & Sloping \\
\hline B & $\begin{array}{c}\text { Terraced } \\
\text { house }\end{array}$ & 3836.17 & 2 & 0 & Isolated & $\begin{array}{l}\text { Reinforced } \\
\text { concrete }\end{array}$ & Sloping \\
\hline C & $\begin{array}{l}\text { Residential } \\
\text { building }\end{array}$ & 7672.32 & 2 & 1 & Isolated & $\begin{array}{l}\text { Reinforced } \\
\text { concrete }\end{array}$ & Flat \\
\hline $\mathrm{D}$ & $\begin{array}{l}\text { Residential } \\
\text { building }\end{array}$ & 4440.34 & 3 & 1 & Isolated & $\begin{array}{l}\text { Reinforced } \\
\text { concrete }\end{array}$ & Sloping \\
\hline E & $\begin{array}{l}\text { Residential } \\
\text { building }\end{array}$ & 4440.34 & 3 & 1 & Isolated & $\begin{array}{l}\text { Reinforced } \\
\text { concrete }\end{array}$ & Flat \\
\hline $\mathrm{F}$ & $\begin{array}{l}\text { Residential } \\
\text { building }\end{array}$ & 6660.60 & 4 & 2 & Slab & $\begin{array}{l}\text { Reinforced } \\
\text { concrete }\end{array}$ & Flat \\
\hline G & $\begin{array}{l}\text { Residential } \\
\text { building }\end{array}$ & 6661.78 & 5 & 1 & Isolated & $\begin{array}{l}\text { Reinforced } \\
\text { concrete }\end{array}$ & Flat \\
\hline $\mathrm{H}$ & $\begin{array}{l}\text { Residential } \\
\text { building }\end{array}$ & 7772.08 & 5 & 2 & Slab & $\begin{array}{l}\text { Reinforced } \\
\text { concrete }\end{array}$ & Sloping \\
\hline I & $\begin{array}{c}\text { Residential } \\
\text { building }\end{array}$ & $12,210.97$ & $6+$ & 1 & Isolated & $\begin{array}{l}\text { Reinforced } \\
\text { concrete }\end{array}$ & Flat \\
\hline $\mathrm{J}$ & $\begin{array}{l}\text { Residential } \\
\text { building }\end{array}$ & $13,320.00$ & $6+$ & 2 & Slab & $\begin{array}{l}\text { Reinforced } \\
\text { concrete }\end{array}$ & Sloping \\
\hline
\end{tabular}

The common characteristics are: mechanical means employed for earth transport, metallic formwork systems, lightweight floor slabs with ceramic hollow blocks, $24 \mathrm{~cm}$ ceramic brick walls for the envelope with an air chamber, polystyrene insulation and stone claddings on the outside, interior divisions with $9 \mathrm{~cm}$-thick ceramic brick walls, gypsum plaster for interior wall finishes, terrazzo flooring, and plaster ceilings.

Regarding carpentry and protection elements, the windows were considered to have painted aluminium frames with thermal bridge breaks, thermal-acoustic glazing $6+12+6$, and PVC blinds without protective steel grids, while the doors are wooden and there are steel railings.

For the installations, an air-conditioning system with a heat pump and console terminal unit is assumed. Hot water is provided by a solar energy system supported by an electric heater. Water is supplied through copper pipes and disposed of through reinforced PVC sewer pipes. Lastly, in order 
to comply with Spanish regulations on accessibility to buildings, lifts are included in cases with more than three floors (e.g., cases D to J from Table 3).

\section{Results and Discussion}

From the analysis of the ten selected typologies described in Table 3, the results obtained by the OERCO2 tool are shown in Figure 2, both in terms of costs $\left(€ / \mathrm{m}^{2}\right)$ and $\mathrm{CF}\left(\mathrm{tCO}_{2} \mathrm{eq} / \mathrm{m}^{2}\right)$. It can be observed that there are no notable differences between the results for these typologies, except for $\mathrm{A}$ and $\mathrm{B}$, which correspond to single-family houses with one or two floors without a basement where the incidence of construction materials and machinery is higher. Thus, statistical studies are complicated since these typologies are less uniform than residential buildings. This causes significant differences even among typologies with the same number of floors. It is also worth mentioning the difference in results between typologies with and without underground floors. Underground floors are taken into account to express results per $\mathrm{m}^{2}$; however, the presence of finishes is much lower than in floors above ground, which decreases the economic and environmental impact per $\mathrm{m}^{2}$. Typologies $\mathrm{C}$ to $\mathrm{J}$ show small differences, but a decrease in the environmental impact in taller buildings is observed, e.g., typology $\mathrm{F}$ (4 floors above ground and 2 underground) produces less environmental impact than typology $\mathrm{G}$ (5 floors above ground and 1 underground).

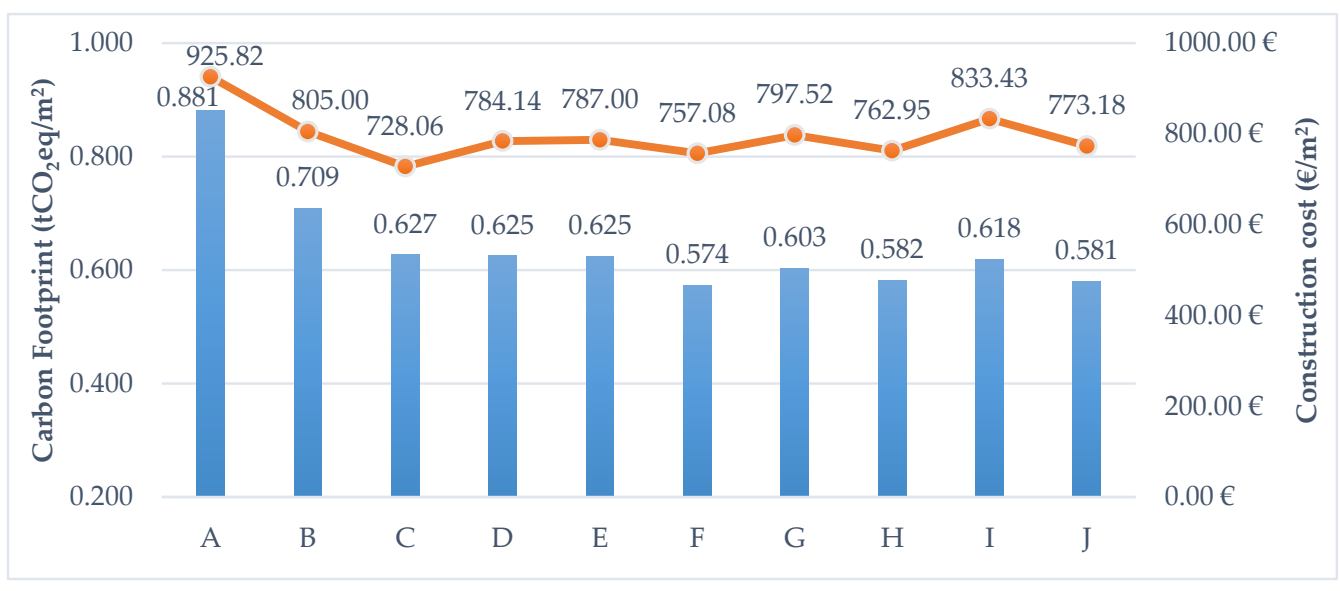

Figure 2. Carbon footprint and costs per area for the 10 selected case studies.

Regarding the influence of the type of foundations, no significant differences among the most used (isolated footings and concrete slab) is observed; however, as the inclusion of pile footings is being considered for future analyses, this might generate considerable variations in the results. Also, the structure (all reinforced concrete) and type of roofs (flat, sloping or mixed) do not cause excessive variation.

The results obtained show that construction materials have more influence (90-95\%) than that of machinery (5-10\%) in the evaluation of the CF. The detailed analysis of materials shows a high incidence of concrete, steel and ceramics, being those with the highest total weight in the construction sector in Spain.

These results have been compared to other studies that focus on the CF of residential buildings in order to check their reliability. The first reference study was published by Chastas et al. [52], who evaluated the embodied energy of 95 residential buildings, of which $64 \%$ where located in Europe, 13\% in America, 16\% in Australia and 7\% in Asia, all of which were built between 1998 and 2017. For the embodied energy assessment, they used a cradle-to-site LCA analysis, that is, the A1-A5 life-cycle phases, which correspond to manufacturing (A1-A3) and construction (A4-A5). The OERCO2 tool was designed by applying these same assumptions. In a primary analysis, results for total carbon emissions were found to lie within the range $348.5-6485 \mathrm{kgCO}_{2} \mathrm{eq} / \mathrm{m}^{2}$ when assuming 
a 50-year service life for the building, with the embodied emissions varying between 128 and $1350 \mathrm{kgCO} 2 \mathrm{eq} / \mathrm{m}^{2}$ and the operational emissions between 97.5 and $6032 \mathrm{kgCO} 2 \mathrm{eq} / \mathrm{m}^{2}$. An earlier survey by De Wolf [53] resulted in the embodied carbon emissions for residential buildings lying within the range $250-750 \mathrm{kgCO} 2 \mathrm{eq} / \mathrm{m}^{2}$, which falls within the range calculated by Chastas et al. [52]. Moreover, the range of embodied emissions for residential buildings is close to that of office buildings, if the ranges of previous surveys by Clark [54] $\left(300-1650 \mathrm{kgCO}_{2} \mathrm{eq} / \mathrm{m}^{2}\right)$ and De Wolf $[53,55]$ $\left(200-1000 \mathrm{kgCO} 2 \mathrm{eq} / \mathrm{m}^{2}\right)$ are considered.

In a second normalization step of their assessment, Chastas et al. [52] apply restrictions to the system boundaries and the reference area, which results in a final sample of 31 case studies, whose total carbon emissions lie within the range $517.5-4475 \mathrm{kgCO}_{2} \mathrm{eq} / \mathrm{m}^{2}$ for a 50 -year lifespan, with embodied emissions decreasing to $179.3-1050 \mathrm{kgCO}_{2} \mathrm{eq} / \mathrm{m}^{2}$. This decrease indicates that the second normalization step increased the homogeneity of the sample and the potential comparability between case studies.

In the case of the present study, the results obtained from the ten typologies analysed belong in the range $580-880 \mathrm{kgCO}_{2} \mathrm{eq} / \mathrm{m}^{2}$, thereby falling within the range determined by Chastas et al. [52] (including the second normalization step) and almost completely within the range determined by De Wolf [53], as can be observed in Figure 3. Since both of these studies employed a cradle-to-site LCA methodology and involved buildings built during the same time span and with a similar estimated service life, they are therefore considered comparable herein.

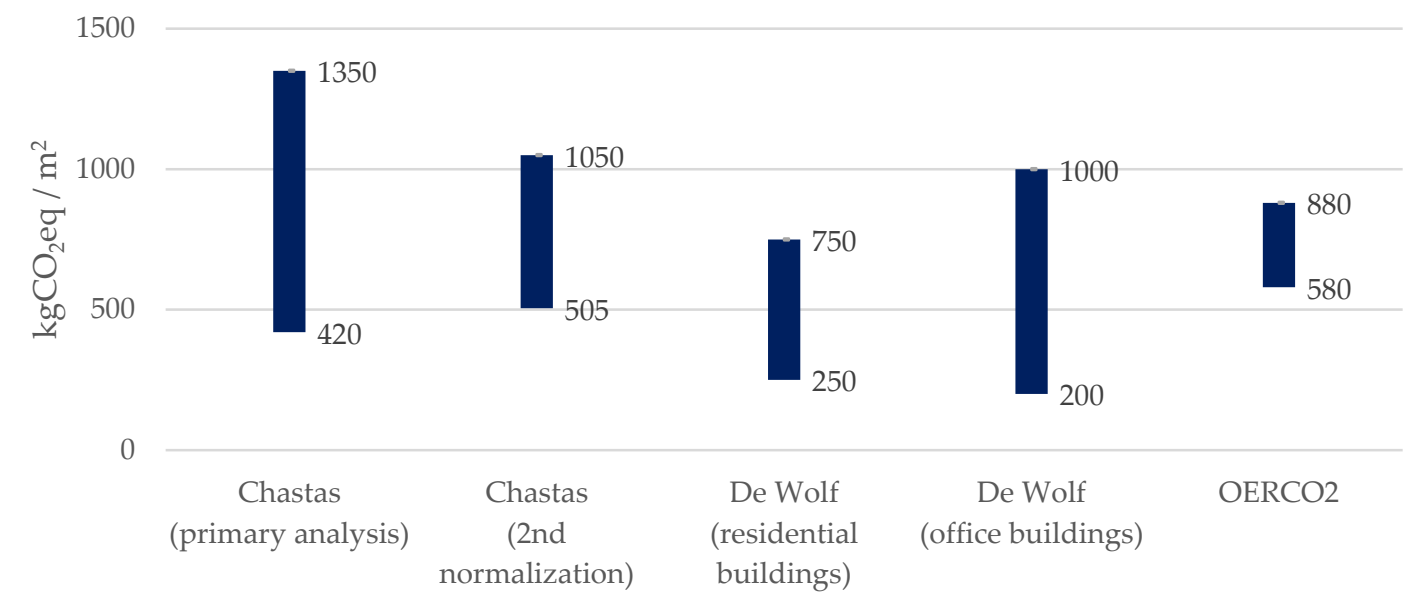

Figure 3. Comparison between the results obtained from the OERCO2 tool and ranges determined by other authors.

In their study, Chastas et al. [52] also classify the results according to the structure type of each building, as shown in Table 4 for both normalization levels. Results from the OERCO2 tool for the typologies studied (Figure 2) are coherent with the ranges determined by Chastas et al. [52] according to the structure type, since nine of the case studies have a reinforced concrete structure and only one uses a masonry structure (type A). Results for the typologies with reinforced concrete structure (types B to J) fall within the range determined by Chastas et al. [52], while the results of typology A fall outside the range. This is due to the fact that typology A is a detached house with only one single floor, a singular typology that was probably not included in their study, whose embodied emissions in construction materials have a stronger incidence on the built-up surface, and hence fails to fit within the calculated range. 
Table 4. Ranges of embodied carbon emissions for different building structures [52].

\begin{tabular}{ccc}
\hline Structure Type & CF 1st Norm. $\left(\mathbf{k g C O} \mathbf{2} \mathbf{e q} / \mathbf{m}^{\mathbf{2}}\right)$ & $\mathbf{C F}$ 2nd Norm.(kgCO $\left.\mathbf{2} \mathbf{e q} / \mathbf{m}^{\mathbf{2}}\right)$ \\
\hline Reinforced concrete & $421-1350$ & $505.7-1050$ \\
Wood & $128-830$ & - \\
Concrete & $140.6-448.5$ & $243-448.5$ \\
Steel & $170-385$ & - \\
Masonry & $161-393.1$ & $274-331.4$ \\
\hline
\end{tabular}

Chastas et al. [52] attributed the wide range of embodied emissions to differences in system boundaries, the source of LCA databases, end-of-life scenarios, the energy mix assumed, or climatic conditions. In the present study, the majority of these factors have been set to similar values in order to ensure uniformity of the results, and therefore the reliability of the designed estimation tool.

\section{Conclusions}

In this paper, a review of the methodologies for the calculation of the $\mathrm{CF}$ of buildings during their life cycle has been carried out, with special focus on those methodologies involving phases A1 to A5 according to the LCA methodology (cradle-to-site). The main aims of the OERCO2 project have been presented, the last of which consists of the development of an online tool that enables the CF of the construction of residential buildings to be determined, especially designed for non-specialized users.

The main innovative aspects of this idea are its methodology, which allows for obtaining very detailed assessments to study more sustainable alternatives, and its educational purpose within the Erasmus + framework, which allows teaching and influencing future professionals in the construction sector on the environmental assessment of building projects.

In order to prove the reliability of the developed tool, ten building typologies which represent construction in Spain over the last decade were analysed, and the results were compared to those obtained through similar studies by other authors. The $\mathrm{CF}$ values obtained fall within the range from 580 to $880 \mathrm{kgCO} 2 \mathrm{eq} / \mathrm{m}^{2}$, thus matching those obtained in the selected comparable studies. These values also show high reliability due to the robustness in the selection of parameters, such as LCA and cost databases, and the similarity between the case studies in terms of location and constructive features. The results also prove that, despite having been obtained through an estimation tool for non-specialized users, they remain coherent with those from other studies where the calculation tools employed were of considerably higher complexity.

The results obtained prove that it is possible to develop a tool that evaluates $\mathrm{CO}_{2}$ emissions generated by construction processes without demanding specialized knowledge regarding environmental impact assessment from the users (students, professionals, administrations, etc.), which leads to a higher acceptance of the basic concepts of sustainability in the building sector. The online platform where the tool is hosted also allows those interested to expand their knowledge in this field.

Further research will be conducted by statistically analysing each of the 140 building typologies to provide the calculation model with greater robustness. Furthermore, the inclusion of these results into BIM environments would generate synergies among BIM specialists and the OERCO2 tool users, who will eventually acquire knowledge on environmental impact assessment concepts. This would help in meeting the European Commission's demand for tools that not only enhance the digitalization of information but that also generate low-carbon production processes and promote a circular economy.

The incorporation of the OERCO2 tool as part of the evaluation process implemented for residential buildings by other environmental certification tools (BREEAM dwellings, VERDE NE, Green Homes GBC Romania, etc.) is currently being studied.

Author Contributions: J.S.-G. and A.M.-R. conceived and designed the experiments; C.R.-C. and D.A.-R. performed the experiments and analysed the data; J.S.-G., C.R.-C., D.A.-R. and A.M.-R. wrote the paper. 
Acknowledgments: This paper and the costs for its publication in open access have been funded by the OERCO2 project (code 2016-1-ES01-KA203-025422), an ERASMUS + project co-funded by the European Union and within the framework of an initiative of 2016 (KA2, Strategic partnerships in the field of higher education), with the support of the Servicio Español Para la Internacionalización de la Educación (SEPIE, Spain).

Conflicts of Interest: The authors declare no conflict of interest. The founding sponsors played no role in the design of the study; in the collection, analyses, or interpretation of data; in the writing of the manuscript, nor in the decision to publish the results.

\section{References}

1. González-Vallejo, P.; Marrero, M.; Solís-Guzmán, J. The ecological footprint of dwelling construction in Spain. Ecol. Indic. 2015, 52, 75-84. [CrossRef]

2. Giesekam, J.; Barrett, J.; Taylor, P.; Owen, A. The greenhouse gas emissions and mitigation options for materials used in UK construction. Energy Build. 2014, 78, 202-214. [CrossRef]

3. Giesekam, J.; Barrett, J.R.; Taylor, P. Construction sector views on low carbon building materials. Build. Res. Inf. 2016, 44, 423-444. [CrossRef]

4. International Organization for Standardization (ISO). Environmental Labels and Declarations_General Principles; UNE-EN ISO 14020; ISO: Geneva, Switzerland, 2002.

5. International Organization for Standardization (ISO). Environmental Labels and Declarations-Self-Declared Environmental Claims (Type II Environmental Labelling); UNE-EN ISO 14021; ISO: Geneva, Switzerland, 2017.

6. International Organization for Standardization (ISO). Environmental Labels and Declarations-Type III Environmental Declarations_Principles and Procedures; UNE-EN ISO 14025; ISO: Geneva, Switzerland, 2006.

7. International Organization for Standardization (ISO). Sustainability of Construction Works-Environmental Product declarations - Core Rules for the Product Category of Construction Products; UNE-EN 15804; ISO: Geneva, Switzerland, 2012.

8. International Organization for Standardization (ISO). Environmental Management_Life Cycle AssessmentPrinciples and Framework; UNE-EN ISO 14040; ISO: Geneva, Switzerland, 2006.

9. International Organization for Standardization (ISO). Environmental Management_Life Cycle AssessmentRequirements and Guidelines; UNE-EN ISO 14044; ISO: Geneva, Switzerland, 2006.

10. International Organization for Standardization (ISO). Sustainability of Construction Works. Assessment of Environmental Performance of Buildings. Calculation Method; UNE-EN 15978; ISO: Geneva, Switzerland, 2012.

11. International Organization for Standardization (ISO). Buildings and Constructed Assets-Service Life Planning_Part 5: Life-Cycle Costing; ISO 15686-5; ISO: Geneva, Switzerland, 2017.

12. International Organization for Standardization (ISO). Environmental Management Systems—Requirements with Guidance for Use; UNE-EN ISO 14001; ISO: Geneva, Switzerland, 2015.

13. Weidema, B.P.; Thrane, M.; Christensen, P.; Schmidt, J.; Lokke, S. Carbon footprint: A catalyst for life cycle assessment? J. Ind. Ecol. 2008, 12, 3-6. [CrossRef]

14. Cagiao, J.; Gómez, B.; Doménech, J.L.; Gutiérrez Mainar, S.; Gutiérrez Lanza, H. Calculation of the corporate carbon footprint of the cement industry by the application of MC3 methodology. Ecol. Indic. 2011, 11, 1526-1540. [CrossRef]

15. Bare, J.C.; Hofstetter, P.; Pennington, D.W.; Haes, H.A.U. Midpoints versus endpoints: The sacrifices and benefits. Int. J. Life Cycle Assess. 2000, 5, 319-326. [CrossRef]

16. Dossche, C.; Boel, V.; De Corte, W. Use of Life Cycle Assessments in the Construction Sector: Critical Review. Proc. Eng. 2017, 171, 302-311. [CrossRef]

17. Geng, S.; Wang, Y.; Zuo, J.; Zhou, Z.; Du, H.; Mao, G. Building life cycle assessment research: A review by bibliometric analysis. Renew. Sustain. Energy Rev. 2017, 76, 176-184. [CrossRef]

18. Buyle, M.; Braet, J.; Audenaert, A. Life cycle assessment in the construction sector: A review. Renew. Sustain. Energy Rev. 2013, 26, 379-388. [CrossRef]

19. Ramesh, T.; Prakash, R.; Shukla, K.K. Life cycle energy analysis of buildings: An overview. Energy Build. 2010, 42, 1592-1600. [CrossRef]

20. Schwartz, Y.; Raslan, R.; Mumovic, D. The life cycle carbon footprint of refurbished and new buildings-A systematic review of case studies. Renew. Sustain. Energy Rev. 2018, 81, 231-241. [CrossRef]

21. Chau, C.K.; Leung, T.M.; Ng, W.Y. A review on life cycle assessment, life cycle energy assessment and life cycle carbon emissions assessment on buildings. Appl. Energy 2015, 143, 395-413. [CrossRef] 
22. Cabeza, L.F.; Rincón, L.; Vilariño, V.; Pérez, G.; Castell, A. Life cycle assessment (LCA) and life cycle energy analysis (LCEA) of buildings and the building sector: A review. Renew. Sustain. Energy Rev. 2014, 29, $394-416$. [CrossRef]

23. Asif, M.; Muneer, T.; Kelley, R. Life cycle assessment: A case study of a dwelling home in Scotland. Build. Environ. 2007, 42, 1391-1394. [CrossRef]

24. Dimoudi, A.; Tompa, C. Energy and environmental indicators related to construction of office buildings. Resour. Conserv. Recycl. 2008, 53, 86-95. [CrossRef]

25. Radhi, H.; Sharples, S. Global warming implications of facade parameters: A life cycle assessment of residential buildings in Bahrain. Environ. Impact Assess. Rev. 2013, 38, 99-108. [CrossRef]

26. You, F.; Hu, D.; Zhang, H.; Guo, Z.; Zhao, Y.; Wang, B.; Yuan, Y. Carbon emissions in the life cycle of urban building system in China-A case study of residential buildings. Ecol. Complex. 2011, 8, 201-212. [CrossRef]

27. Cellura, M.; Guarino, F.; Longo, S.; Mistretta, M. Energy life-cycle approach in Net zero energy buildings balance: Operation and embodied energy of an Italian case study. Energy Build. 2014, 72, 371-381. [CrossRef]

28. Scheuer, C.; Keoleian, G.A.; Reppe, P. Life cycle energy and environmental performance of a new university building: Modeling challenges and design implications. Energy Build. 2003, 35, 1049-1064. [CrossRef]

29. SpainGBC LEED Certificate. Available online: http://www.spaingbc.org/web/leed-4.php (accessed on 22 December 2017).

30. BREEAM BREEAM ES Website. Available online: http:/ / www.breeam.es/ (accessed on 22 December 2017).

31. SpainGBC VERDE Tool Website. Available online: http://www.gbce.es/es/pagina/herramientas-deevaluacion-de-edificios (accessed on 22 December 2017).

32. Asociación Ecómetro Ecometro LCA Tool Website. Available online: http://acv.ecometro.org/ (accessed on 22 December 2017).

33. Spain METDA Simplified Procedures for Building Energy Certification. Available online: http:/ / www.minetur.gob.es/ENERGIA/DESARROLLO/EFICIENCIAENERGETICA/ CERTIFICACIONENERGETICA/DOCUMENTOSRECONOCIDOS/Paginas/procedimientoscertificacion-proyecto-terminados.aspx (accessed on 22 December 2017).

34. Spain MPW Unified Tool LIDER-CALENER. Available online: http://www.codigotecnico.org/ index.php/menu-recursos/menu-aplicaciones/282-herramienta-unificada-lider-calener (accessed on 22 December 2017).

35. CYPE Ingenieros CYPETHERM HE. Available online: http://cypeterm-he.cype.es/ (accessed on 22 December 2017).

36. ITeC BEDEC Website. Available online: http://www.itec.es/nouBedec.e/bedec.aspx (accessed on 3 December 2013).

37. Ecoinvent Association Ecoinvent Database v3. Available online: http://www.ecoinvent.org/database/ database.html (accessed on 18 March 2018).

38. Martínez-Rocamora, A.; Solís-Guzmán, J.; Marrero, M. LCA databases focused on construction materials: A review. Renew. Sustain. Energy Rev. 2016, 58, 565-573. [CrossRef]

39. PRé Sustainability SimaPro 8. Available online: https:/ / simapro.com/ (accessed on 28 March 2018).

40. SOFIAS Project SOFIAS Project Website. Available online: http://www.sofiasproject.org/ (accessed on 22 December 2017).

41. e2CO2cero e2CO2cero Tool Website. Available online: http://tienda.e2co2cero.com/ (accessed on 22 December 2017).

42. Marrero, M.; Puerto, M.; Rivero-Camacho, C.; Freire-Guerrero, A.; Solís-Guzmán, J. Assessing the economic impact and ecological footprint of construction and demolition waste during the urbanization of rural land. Resour. Conserv. Recycl. 2017, 117, 160-174. [CrossRef]

43. Martínez-Rocamora, A.; Solís-Guzmán, J.; Marrero, M. Toward the Ecological Footprint of the use and maintenance phase of buildings: Utility consumption and cleaning tasks. Ecol. Indic. 2016, 69. [CrossRef]

44. Solís-Guzmán, J.; González-Vallejo, P.; Martínez-Rocamora, A.; Marrero, M. The Carbon Footprint of Dwelling Construction in Spain. In The Carbon Footprint Handbook; CRC Press-Taylor \& Francis Group: Boca Raton, FL, USA, 2015; pp. 261-283, ISBN 978-1-4822-6222-3.

45. Solís-Guzmán, J.; Marrero, M.; Ramírez-de-Arellano, A. Methodology for determining the ecological footprint of the construction of residential buildings in Andalusia (Spain). Ecol. Indic. 2013, 25, 239-249. [CrossRef] 
46. Solís-Guzmán, J.; Marrero, M.; Montes-Delgado, M.V.; Ramírez-de-Arellano, A. A Spanish model for quantification and management of construction waste. Waste Manag. 2009, 29, 2542-2548. [CrossRef] [PubMed]

47. Martínez Rocamora, A.; Solís-Guzmán, J.; Marrero, M. Ecological footprint of the use and maintenance phase of buildings: Maintenance tasks and final results. Energy Build. 2017, 155. [CrossRef]

48. Alba-Rodríguez, M.D.; Martínez-Rocamora, A.; González-Vallejo, P.; Ferreira-Sánchez, A.; Marrero, M. Building rehabilitation versus demolition and new construction: Economic and environmental assessment. Environ. Impact Assess. Rev. 2017, 66. [CrossRef]

49. Andalusia Government Andalusia Construction Cost Database (ACCD). Available online: http:/ / www.juntadeandalucia.es/organismos/fomentoyvivienda/areas/vivienda-rehabilitacion/ planes-instrumentos/paginas/bcca-sept-2017.html (accessed on 21 March 2018).

50. Marrero, M.; Ramirez-De-Arellano, A. The building cost system in Andalusia: Application to construction and demolition waste management. Constr. Manag. Econ. 2010, 28, 495-507. [CrossRef]

51. González-Vallejo, P.; Solís-Guzmán, J.; Llácer, R.; Marrero, M. La construcción de edificios residenciales en España en el período 2007-2010 y su impacto según el indicador Huella Ecológica. Inf. Constr. 2015, 67, e111. [CrossRef]

52. Chastas, P.; Theodosiou, T.; Kontoleon, K.J.; Bikas, D. Normalising and assessing carbon emissions in the building sector: A review on the embodied $\mathrm{CO}_{2}$ emissions of residential buildings. Build. Environ. 2018, 130, 212-226. [CrossRef]

53. De Wolf, C. Material Quantities in Building Structures and Their Environmental Impact; Massachusetts Institute of Technology: Cambridge, MA, USA, 2014.

54. Clark, D. What Colour is Your Building?: Measuring and Reducing the Energy and Carbon Footprint of Buildings; RIBA Publishing: Marylebone, UK, 2012; ISBN 978-1859464472.

55. De Wolf, C.; Pomponi, F.; Moncaster, A. Measuring embodied carbon dioxide equivalent of buildings: A review and critique of current industry practice. Energy Build. 2017, 140, 68-80. [CrossRef]

(C) 2018 by the authors. Licensee MDPI, Basel, Switzerland. This article is an open access article distributed under the terms and conditions of the Creative Commons Attribution (CC BY) license (http:/ / creativecommons.org/licenses/by/4.0/). 